\title{
KLASTER INDUSTRI SEBAGAI STRATEGI PENINGKATAN DAYA SAING AGROINDUSTRI BIOENERGI BERBASIS KELAPA SAWIT
}

\author{
Petir Papilo*), Tajuddin Bantacut \\ Program Studi Teknik Industri - UIN Sultan Syarif Kasim Riau
}

(Received: November 11, 2015 / Accepted: February 6, 2016)

\begin{abstract}
Abstrak
Kajian ini bertujuan untuk memberikan gambaran tentang dampak dari pelaksanaan program klaster industri terhadap peningkatan daya saing industri bioenergi berbasis kelapa sawit nasional. Melalui pendekatan analisis perbandingan yang merujuk pada berbagai kajian terdahulu, dapat diketahui bahwa penerapan strategi klaster industri memberikan pengaruh positif terhadap tiga klaster agroindustri kelapa sawit nasional yang berada di Provinsi Riau, Sumatra Utara dan Kalimantan Timur. Berdasarkan penilaian terhadap empat elemen daya saing, seperti aglomerasi perusahaan, nilai tambah dan rantai nilai, jejaring kerjasama serta infrastruktur ekonomi, menunjukkan bahwa telah terjadi peningkatan nilai daya saing dari ketiga klaster industri sebesar masing-masingnya 0,503, 0294 dan 0,232.
\end{abstract}

Kata Kunci : biodiesel; daya saing; kelapa sawit; klaster industri

\begin{abstract}
This study aims to provide an overview of the implementation impact of industrial cluster program to increase the competitiveness of the national agro-industry bioenergy based on palm oil. Through a comparative analysis approach that refers to previous studies, it is known that the implementation of the industrial cluster strategy has a positive influence on the three national oil palm agro-industrial clusters that located in the Riau Province, North Sumatra and East Kalimantan. Based on the assessment of the four elements of competitiveness, such as agglomeration company, value-added and value chains, networks and infrastructure, indicate that there has been an increase in the competitiveness value of the three clusters agro-industries by each 0.503, 0294 and 0.232.
\end{abstract}

Keywords: biodiesel; competitivenes; industrial cluster; palm oil

\section{Pendahuluan}

Secara nasional, saat ini kemampuan daya saing industri di Indonesia, cenderung mengalami penurunan. Hal ini dibuktikan dari laporan tahunan yang disusun oleh World Economic Forum (WEF) dan Bank Dunia yang secara kontinyu melakukan penilaian daya saing global suatu negara. WEF membagi sejumlah faktor penentu daya saing ke dalam tiga kolompok (tiga subindeks), antara lain : (1) persyaratan-persyaratan dasar, (2) pendorong efisiensi serta (3) faktor-faktor inovasi dan kecanggihan. Faktor-faktor ini dianggap sebagai motor utama penggerak pertumbuhan ekonomi.

Berdasarkan Indeks Daya Saing Global atau Global Competitiveness Index (GCI), WEF menunjukkan bahwa posisi Indonesia berada di peringkat 50 dari 144 negara pada periode tahun 2012 2013. Posisi ini relatif memburuk dibandingkan dengan

\footnotetext{
${ }^{*}$ Penulis Korespondensi. email: pilo_ukm@yahoo.com
}

periode sebelumnya (2011-2012) yakni di peringkat 46 dari 142 negara, dan bahkan lebih rendah dibandingkan dengan periode 2010-2011 yang berada pada peringkat 44 dari 139 negara. Hasil penilaian ini juga diperkuat dari laporan tahun Bank Dunia. Berdasarkan 11 indikator penilaian daya saing ekonomi yang digunakan, menunjukkan bahwa daya saing Indonesia terus mengalami penurunan berturut-turut yaitu pada posisi 121 tahun 2011, turun ke posisi 129 di tahun 2012, (Tambunan, 2013). Oleh karenanya, diperlukan upayaupaya serius dan bersifat strategis demi meningkatkan daya saing industri nasional dari berbagai sektor potensial yang ada.

Kelapa sawit merupakan komoditas pertanian yang paling potensial yang dimiliki Indonesia saat ini. Pada tahun 2013, tercatat bahwa tingkat produksi minyak sawit kasar (crude palm oil - CPO) Indonesia dilihat dari tiga sumber perkebunan (rakyat, swasta dan negara) adalah sebesar 23.123.359 Ton, dengan laju pertumbuhan $33,3 \%$ dan didominasi oleh perkebunan milik swasta dengan tingkat pertumbuhan $54,8 \%$. Selain 
itu, telah terjadi peningkatan volume ekspor minyak CPO hingga lebih dari 20 juta ton, dimana $70 \%$ diantaranya ekspor pada tiga wilayah negara yakni India, Cina dan Uni Eropa. (GAPKI, 2014).

Pada Awalnya, CPO merupakan produk eksport utama yang dapat dihasilkan dari agroindustri kelapa sawit di Indonesia. Namun saat ini, agroindustri kelapa sawit nasional juga telah mengolah produk lain seperti PKO (Palm Kernel Oil) dan bahkan sampai kepada produk turunan yang memiliki nilai tambah lebih tinggi. Hambali E (2010), telah membagi CPO dan PKO menjadi beberapa produk turunan utama, diantaranya minyak goreng (olein), margarin, Palm Mid Fraction (PMF), Palm Fatty Acid Destillate (PFAD), asam lemak dan bioenergi, dalam hal ini adalah biodiesel.

Industri bioenergi khususnya biodiesel merupakan industri hilir minyak sawit yang masih tergolong baru di Indonesia. Momentum pertumbuhan industri ini, mulai terjadi ketika harga Bahan Bakar Minyak (BBM) fosil mengalami kenaikan secara signifikan di pasar dunia khususnya setelah tahun 2003. Selain itu, keprihatinan dunia akan peningkatan pemanasan global yang diakibatkan emisi $\mathrm{CO}_{2}$ dari konsumsi energi fosil, juga ikut merangsang tumbuhnya industri biofuel di seluruh dunia termasuk di Indonesia.

Di beberapa negara, biodiesel juga dapat dihasilkan dari komoditas-komoditas lainnya, diantaranya kacang kedele (soybean), jarak pagar (rapeseed) serta biji bunga matahari. FAPRI memproyeksikan bahwa hingga tahun 2020, perkembangan produksi diodiesel dunia menunjukkan trend pertumbuhan yang positif. Kawasan Eropa diproyeksikan masih memegang peran penting dalam pasar biodiesel dunia, dengan produksi sebesar 15.14 juta kilo liter atau dengan penguasaan pangsa pasar $57.17 \%$. Urutan kedua adalah USA, dengan pangsa pasar 14,18\%, dan dengan volume produksi 3.76 juta kilo liter. Sementara Argentina memiliki pangsa produksi $13.26 \%$, Brazil $11.18 \%$. Sedangkan Asia, dalam hal ini Indonesia dan Malaysia masing-masing diproyeksikan hanya memiliki pangsa pasar sebesar $3.49 \%$ dan $0.72 \%$. Sementara, disisi konsumsi juga terus mengalami peningkatan di setiap wilayah. (GAPKI, 2014).

Jika dilihat dari kemampuan yang ada, produksi biodiesel di Indonesia relatif lebih rendah dibandingkan beberapa negara produsen lainnya seperti di kawasan Uni Eropa dan Amerika. Hal ini tidak terlepas dari daya saing yang ada, ditambah lagi prioritas pemanfaatan hasil minyak kelapa sawit di Indonesia, relatif lebih banyak dimanfaatkan untuk menghasilkan produk lainnya selain biodiesel, seperti minyak goreng dan margarin.

Pemerintah Indonesia terus berupaya untuk memaksimalkan pemanfaatan komoditas pertanian dalam negeri khususnya kelapa sawit, guna memenuhi kebutuhan energi nasional. Keseriusan ini ditunjukkan dengan dikeluarkannya Peraturan Menteri ESDM No. 25 Tahun 2013 yang merupakan perubahan atas Peraturan Menteri ESDM No. 32 Tahun 2008, dimana dalam peraturan tersebut pemerintah menegaskan perlu dilakukan peningkatan porsi pemanfaatan bahan bakar nabati (BBN) dalam pemenuhan energi bahan bakar minyak (BBM) sebesar $10 \%$ pada bahan bakar biodiesel. Pemanfaatan ini dilakukan melalui mekanisme blending (pencampuran biodiesel dengan solar) atau yang dikenal dengan istilah B10, dimana dari setiap liter BBM perlu ditambahkan $10 \%$ biodiesel

Upaya ini cukup memberikan hasil positif bagi perekonomian nasional. Menurut data Direktorat Bioenergi ESDM, tahun 2013 penerapan kebijakan ini, mampu menghemat devisa negara (khususnya dari pemanfaatan biodiesel) sebesar US\$ 831 Juta. Bahkan, pada tahun 2014 Pemerintah Indonesia kembali merevisi peraturan sebelumnya, dengan mengeluarkan Permen ESDM No. 20 Tahun 2014, dimana porsi pemanfaatan $\mathrm{BBN}$ dalam BBM mengalami peningkatan menjadi 20\% (khusus untuk pemanfaatan biodiesel di bidang transportasi dan industri). Meskipun Rencana penerapan ini baru akan dilaksanakan pada tahun 2016, secara ekonomis pemerintah menargetkan akan terjadi penghematan sebesar US\$ 3 Miliar. (EBTKE, 2014).

Kebijakan pemanfaatan dan pengembangan biodiesel ini, perlu ditunjang dengan konsep dan strategi yang jelas dan terencana, sehingga kebutuhan bioenergi yang terus meningkat dapat terpenuhi. Lebih jauh lagi, peningkatan produksi biodiesel dalam negeri diharapkan pula mampu meningkatkan daya saing industri bioenergi nasional dalam upaya peningkatan pangsa pasar bioenergi secara global yang berimbas kepada peningkatan pendapatan devisa negara. Oleh karenanya diperlukan strategi terbaik yang memungkinkan untuk diterapkan, sehingga dapat memberikan hasil-hasil ekonomi secara maksimal.

Salah satu strategi peningkatan daya saing industri bioenergi yang mulai dijalankan saat ini adalah pengembangan kawasan klaster industri. Pemerintah melalui Peraturan Nomor 24 Tahun 2009 menegaskan bahwa, pembangunan kawasan industri bertujuan untuk mengendalikan pemanfaatan ruang wilayah dan sekaligus meningkatkan daya saing industri dan investasi serta memberikan kepastian lokasi dalam perencanaan dan pembangunan infrastruktur yang terkoordinasi antar sektor (Tambunan, 2013). Melalui pengembangan klaster industri, pada suatu kawasan tertentu, diharapkan pula akan mengurangi biaya transportasi dan transaksi, terjadinya peningkatan efisiensi, penciptaan aset secara kolektif, serta mendorong terciptanya inovasi (Hambali E, 2005).

Penelitian berkait dengan klaster industri sebagai strategi peningkatan daya saing industri bioenergi berbasis kelapa sawit ini bertujuan untuk memberikan gambaran tentang perkembangan klaster industri bioenergi yang ada di Indonesia saat ini. Melalui analisis secara deskriptif, serta review terhadap beberapa literatur terkait, diharapkan dapat memberikan gambaran tentang permasalahan yang ada, efektifitas hubungan keterkaitan antar pelaku usaha serta upayaupaya yang dapat dilakukan demi meningkatkan daya saing klaster industri bioenergi nasional. 
Tinjuan Pustaka

Penelitian Terkait Klaster Agroindustri Berbasis Kelapa Sawit

Beberapa penelitian terkait dengan strategi pengembangan klaster industri dan bioenergi berbasis kelapa sawit diantaranya adalah yang dihasilkan oleh Said Didu (2000), Hambali E (2005), Udayana (2010), Hambali E (2010), Joni R (2012), dan Utama DN (2012). Selain itu, beberapa penelitian terkait daya saing dan nilai tambah agroindustri kelapa sawit diantaranya yang dilakukan Sari (2008), dan Hidayat (2012).

Said Didu (2000) telah melakukan penelitian tentang rancang bangun strategi pengembangan agroindustri kelapa sawit nasional. Melalui analisis dengan pendekatan sistem pakar, dapat diketahui bahwa beberapa faktor yang mempengaruhi pengembangan agroindustri kelapa sawit antara lain adalah faktor ketersediaan dana, kondisi permintaan pasar serta kebijakan pemerintah. Khusus dari sisi kebijakan, faktor lain yang juga penting untuk diperhatikan antara lain adalah harga jual tandan buah segar (TBS) kelapa sawit, gaji/ upah serta penetapan sistem perpajakan.

Menurut Hambali E (2005), strategi pengembangan agroindustri kelapa sawit harus diarahkan ke dalam bentuk klaster agroindustri hilir, dimana orientasi produksi lebih fokus kepada produkproduk turunan minyak kelapa sawit. Jadi untuk dapat memberikan nilai tambah dari perkebunan dan pabrik kelapa sawit, hilirisasi produksi agroindustri kelapa sawit harus diarahkan kepada produksi produk-produk turunan seperti minyak goreng, margarin, gliserol, asam lemak serta produk-produk oleo kimia lainnya.

Selain produk-produk pangan dan oleo kimia, hilirisasi agroindustri kelapa sawit juga dapat diarahkan pada industri bioenergi terutama melalui pemanfaatan biomasa limbah kelapa sawit. Beberapa biomasa kelapa sawit yang potensial untuk dikembangkan sebagai sumber energi diantaranya adalah tandan kosong, cangkang serta limbah cair atau yang dikenal dengan POME (Palm Oil Mill Effluent) (Hambali E, 2010); (Soerawidjaja, 2011).

Udayana (2010) telah pula mengkaji beberapa resiko berkait pemanfaatan kelapa sawit sebagai sumber energi seperti halnya bahan baku BBN (biodiesel). Menurutnya terdapat tiga kelompok resiko pada pemanfaatan kelapa sawit sebagai sumber bahan baku biodiesel, yakni : (1) resiko pengadaan bahan baku, (2) resiko proses dan (3) resiko pemasaran. Adapun faktor resiko pengadaan bahan baku yang perlu diperhatikan diantaranya adalah waktu dan jumlah ketersediaan pasokan, harga jual, mutu serta biaya pembelian. Resiko dari sisi proses diantaranya kualitas biodiesel, kinerja mesin dan peralatan, biaya produksi biodiesel, pemeliharaan mesin serta lokasi pengolahan. Sedangkan resiko dari sisi pemasaran diantaranya terdiri dari faktor kepuasan konsumen, posisi persaingan, distribusi, kebijakan pemerintah, dan peningkatan harga bahan baku.
Sebaliknya, Joni R (2012) telah mengkaji tentang dampak pemanfaatan komoditas kelapa sawit sebagai bahan baku bioenergi terhadap perkebunan dan agroindustri minyak kelapa sawit. Pemanfaatan hasil kelapa sawit sebagai sumber bahan baku biodiesel telah menimbulkan beberapa dampak positif maupun negatif terhadap harga minyak kelapa sawit serta produk turunan lainnya seperti minyak goreng dan margarin. Beberapa dampak positif pemanfaatan biodiesel terhadap agroindustri kelapa sawit diantaranya telah terjadi peningkatan produksi, konsumsi dan harga minyak kelapa sawit dan harga tandan buah segar kelapa sawit. Disisi lain juga menimbulkan dampak negatif, yakni terjadi peningkatan harga minyak goreng yang berdampak pada produksi dan konsumsi minyak goreng.

Utama DN (2012) juga telah melakukan penelitian berkait pengembangan klaster industri bioenergi berbasis kelapa sawit. Melalui pendekatan sistem, telah dibangun suatu model cerdas manajemen rantai pasok industri bioenergi berbasis kelapa sawit. Dengan menggunakan metode Optimasi Koloni Semut (ant colony) telah dibangun model pencarian optimum rantai pasok mulai dari perkebunan di tingkat hulu hingga menghasilkan produk bioenergi di tingkat hilir. Dari penelitian ini dapat diketahui bahwa faktor optimasi yang paling menentukan adalah faktor jarak.

Berkait dengan daya saing agroindustri kelapa sawit, Sari (2008) telah melakukan penelitian tentang analisis daya saing dan strategi ekspor kelapa sawit (CPO) Indonesia di pasar internasional. Melalui analisis kuantitatif dengan pendekatan Revealed Comparative Advantage (RCA) dan analisis kualitatif dengan pendekatan SWOT Analysis, penelitian ini mendapatkan bahwa pangsa pasar internasional dari agroindustri kelapa sawit Indonesia adalah lebih baik dibandingkan dengan negara Malaysia dan Kolumbia. Dari kajian ini dapat diketahui pula bahwa CPO produksi nasional memiliki keunggulan komparatif dibandingkan negara lainnya. Selain itu beberapa faktor kendala dalam pemasaran produk CPO nasional diantaranya adalah kebijakan pemerintah, nilai produk dan produktivitas yang masih rendah, serta masih tingginya biaya ekspor produk CPO.

Menurut Hidayat (2012), salah satu faktor penentu daya saing pengembangan agroindustri kelapa sawit adalah faktor keseimbangan nilai tambah yang didasari pada resiko kerugian antar aktor, mulai dari level pemasok bahan baku di tingkat petani, pedagang pengepul TBS, pabrik CPO, pabrik minyak goreng, distributor hingga konsumen. Dari hasil kajian ini, dapat diketahui bahwa selain konsumen kelompok aktor yang mendapatkan porsi keuntungan paling tinggi adalah pabrik pengolahan CPO dan industri minyak goreng. Sementara kelompok petani merupakan kelompok yang juga memperoleh nilai tambah yang cukup tinggi, meskipun pada kenyataannya dari porsi keuntungan dianggap masih rendah. 


\section{Konsep Klaster Industri}

Istilah "klaster (cluster)" mempunyai pengertian harfiah sebagai kumpulan, kelompok, himpunan, atau gabungan obyek tertentu yang memiliki kesamaan atau atas dasar karakteristik tertentu. Dalam konteks ekonomi/bisnis, "klaster industri (industrial cluster)" merupakan terminologi yang mempunyai pengertian khusus tertentu. Walaupun begitu, dalam literatur, istilah "klaster industri" diartikan dan digunakan secara beragam.

Secara umum, Michael Porter mendefinisikan klaster industri sebagai konsentrasi geografis dari beberapa perusahaan yang saling berhubungan dan lembaga pada bidang tertentu. (Menzel dan Fornahl, 2009). Hal ini menjelaskan bahwa, dalam sebuah klater industri tidak hanya terdiri dari perusahaan, namunnya juga di dukung oleh adanya institusi-institusi lainnya. Jadi, dapat dikatakan pula bahwa klaster industri merupakan sekumpulan perusahaan dan lembagalembaga terkait di bidang tertentu yang berdekatan secara geografis dan saling terkait karena "kebersamaan (commonalities) dan komplementaritas" (Porter, 2000).

Menzel dan Fornahl (2009), menggambarkan suatu klaster terdiri dari interkoneksi antar berbagai perusahaan dalam ruang dan batas-batas atau bidang industri (tematik) tertentu, sebagai berikut :

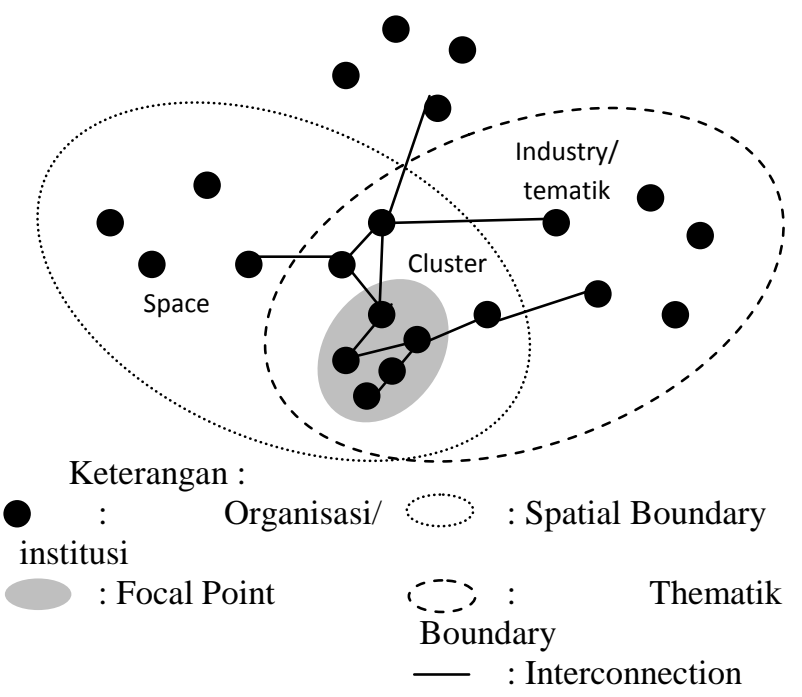

Gambar 1. Elemen-elemen dalam klaster industri (Menzel dan Fornahl, 2009)

\section{Model Daya Saing Berlian Porter}

Berbagai model untuk mempelajari klaster industri telah dikembangkan oleh berbagai peneliti dan pakar selama beberapa dekade terakhir. Salah satu model yang sering dijadikan sebagai acuan dan rujukan dalam pengembangan klaster industri adalah Model Berlian Porter (Porter's Diamond Model). Konsep "the four diamond" Porter ini mengajukan empat faktor yang saling terkait yang merupakan penentu keunggulan daya saing suatu industri, yaitu:

- Strategi perusahaan, struktur dan persaingan,

- Kondisi permintaan,
- Kondisi faktor,

- Industri terkait dan pendukung.

Porter selanjutnya juga menambahkan faktor chance dan government dalam model berlian tersebut, dimana kedua faktor tambahan ini bukanlah determinan tetapi berpengaruh terhadap keempat determinan di atas. Keenam faktor tersebut secara bersamaan membentuk sebuah sistem yang berbeda dari suatu lokasi dengan lokasi yang lain, dan hal ini menjelaskan mengapa beberapa perusahaan (industri) hanya berhasil di suatu lokasi tertentu saja. Tidak semua faktor harus optimal dalam menjamin keberhasilan sebuah perusahaan atau industri, (Porter, 2000).

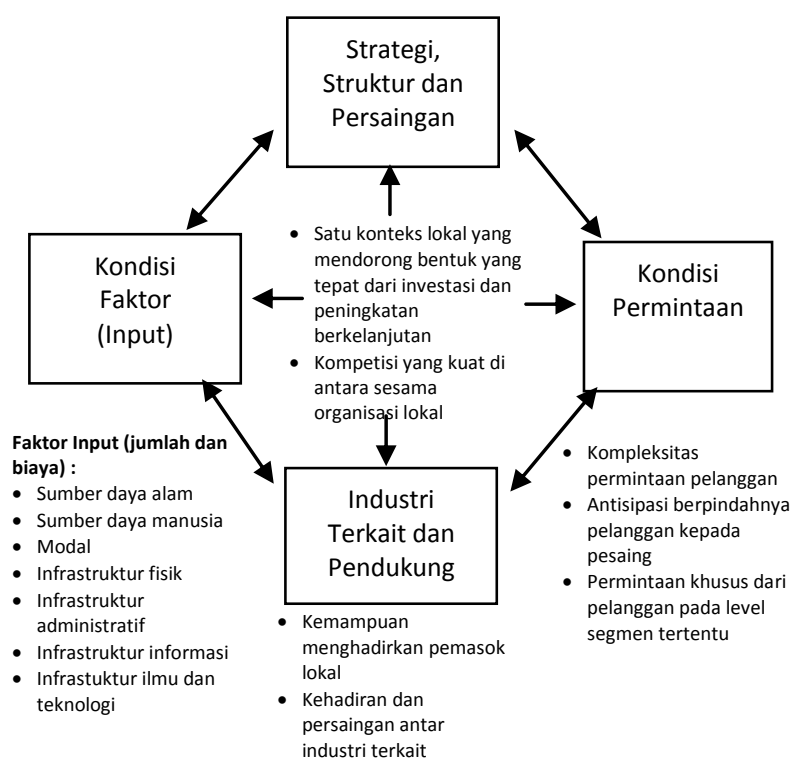

Gambar 2. Model Berlian (diamond) Porter (Porter, 2000)

Secara lebih detail, masing-masing faktor dari model berlian Porter dapat dijelaskan sebagai berikut (Porter, 1990) :

- Strategi perusahaan, struktur, dan persaingan (firm strategy, structure, and rivalry) merupakan suatu kondisi yang menentukan bagaimana perusahaan muncul/tumbuh, terorganisasi dan dikelola, serta sifat persaingan usaha di negara yang bersangkutan.

- Kondisi permintaan (demand conditions) merupakan sifat permintaan domestik (home demand) untuk produk (barang dan/atau jasa) dari industri yang bersangkutan. Porter mengemukakan bahwa inti penting dari faktor ini adalah komposisi permintaan domestik merupakan "akar" bagi keunggulan daya saing, sementara ukuran dan pola pertumbuhannya dapat memperkuat keunggulan tersebut dengan mempengaruhi perilaku investasi, timing, dan motivasi. Hal lain yang juga turut berkontribusi adalah mekanisme internasionalisasi "penarikan" permintaan domestik ke luar negeri.

- Kondisi faktor (factor conditions) kondisi yang menggambarkan posisi suatu negara dalam "faktorfaktor produksi" (input yang dibutuhkan untuk 
bersaing), seperti tenaga kerja atau infrastruktur, yang diperlukan untuk bersaing dalam suatu industri.

- Industri terkait dan pendukung (related and supporting industries), kehadiran industri-industri pendukung dan yang terkait di negara yang bersangkutan yang memiliki daya saing (kompetitif) secara internasional. Kunci paling signifikan dalam hal ini adalah industri pendukung dan terkait yang dinilai penting bagi inovasi suatu industri, atau yang memberikan kesempatan/peluang untuk berbagi aktivitas kritis suatu industri.

Dalam model berlian tersebut, "kejadian-kejadian yang bersifat kebetulan" (chance events) dan pemerintah terkait dengan hal-hal di luar kemampuan perusahaan, seperti adanya penemuan murni, diskontinuitas teknologi yang besar, diskontinuitas dalam biaya input, perubahan yang signifikan dalam pasar keuangan dunia atau nilai tukar, berkembangnya permintaan regional atau dunia, keputusan politik pemerintah asing, dan peperangan.

\section{Bioenergi Berbasis Kelapa Sawit}

Secara sederhana, bioenergi dapat didefinisikan sebagai energi yang diperoleh datau dihasilkan dari sumber biomasa. Biomasa pula merupakan bahan-bahan organik yang berumur relatif muda yang berasal dari tumbuhan/ hewan, produk dan limbah industri budidaya seperti pertanian, perkebunan, kehutanan dan peternakan, (Soerawidjaja, 2011). Biomass juga dapat didefinisikan sebagai bagian dari suatu produk yang dapat terurai secara biologi, limbah dan sisa dari pertanian (termasuk zat nabati dan hewani), kehutanan dan industri terkait, serta bagian dari limbah industri dan limbah kota yang terdegradasi secara biologis (Biomas Energy Europe, 2010a).

Bioenergi tersedia dalam bentuk cair seperti biodiesel atau bioethanol, berwujud gas atau yang dikenal sebagai biogas serta berwujud padat seperti pelet, briket atau biobriket (Soerawidjaja, 2011). Pemanfaatan bioenergi sangat luas diantaranya penghasil panas (heat), sumber energi listrik (electricity) serta sebagai bahan bakar (fuel) (BPPT, 2011).

Kelapa sawit merupakan salah satu komoditas potensial sebagai sumber penghasil bioenergi. CPO merupakan bahan baku utama untuk menghasilkan bahan bakar nabati berupa biodiesel. Sedangkan limbah perkebunan kelapa sawit dalam bentuk tandan kosong, serat, cangkang serta limbah cair (POME), berpotensi untuk dimanfaatkan sebagai sumber energi listrik (Hambali E, 2010).

Produk bioenergi yang paling potensial dan memiliki nilai ekonomi paling tinggi yang dapat dihasilkan dari kelapa sawit adalah dalam bentuk bahan bakar nabati, yakni biodiesel. Saat ini, produk biodiesel nasional lebih banyak dieksport ke luar negara dikarenakan memberikan keuntungan lebih maksimal. Secara umum, harga biodiesel dunia diproyeksikan akan cenderung mengalami peningkatan dari harga 1.52
US/liter pada tahun 2014 menjadi 1.62 US/liter pada tahun 2021 (GAPKI, 2014).

\section{Bahan Dan Metode}

Kajian ini merupakan review atas hasil -hasil penelitian sebelumnya yang berkait dengan pengembangan klaster agroindustri kelapa sawit, khususnya dalam menghasilkan biodiesel. Melalui analisis secara deskriptif terhadap beberapa literatur terkait serta mengacu kepada data-data sekunder yang ada, akan dilakukan suatu penggambaran tentang kondisi daya saing dan perkembangan klaster agroindustri berbasis kelapa sawit nasional. Beberapa sumber data sekunder yang menjadi rujukan dalam kajian ini antara lain, Data Statistik Pertanian Indonesia 2014, Data Statistik Agroindustri Kelapa Sawit, GAPKI 2014, Data Statistik Energi Baru dan Terbarukan, EBTKE 2014, serta hasil-hasil kajian penelitian lainnya.

Adapun aspek daya saing yang dikaji, merujuk kepada faktor-faktor yang terdapat dalam Model Berlian Porter. Aspek daya saing tersebut terbagi ke dalam beberapa kondisi diantaranya, kondisi faktor, kondisi permintaan, strategi pengembangan perusahaan inti dan struktur persaingan, serta kondisi industri terkait dan industri pendukung.

Selain itu juga dilakukan analisis secara deskriptif berdasarkan kajian terdahulu, yakni Hasil Evaluasi Tim Ahli Klaster Industri Kementrian Perindustrian Nasional tahun 2012, berkait perkembangan klaster agroindustri kelapa sawit yang terdapat pada tiga wilayah yakni Riau, Sumatra Utara dan Kalimantan Timur. Penilaian dilakukan berdasarkan empat elemen daya saing yang terdiri dari aglomerasi perusahaan, nilai tambah dan rantai nilai, jejaring kerja sama, dan infrastruktur. Keempat elemen ini akan diukur berdasarkan sembilan indikator penilaian yang dikembangkan oleh Feser (1999).

\section{Hasil Dan Pembahasan \\ Pasokan dan Kebutuhan Bahan Baku.}

Indonesia merupakan produsen kelapa sawit terbesar di dunia. Hingga tahun 2014, total areal perkebunan kelapa sawit nasional mencapai 10,956,231 Ha dengan laju pertumbuhan luas lahan sebesar 4,69\%. Dari keseluruhan areal perkebunan yang ada, dapat menghasilkan TBS kelapa sawit sebanyak 29,344,479 ton dengan laju pertumbuhan sebesar $5.62 \%$ (Deptan, 2014).

CPO dan PKO merupakan bahan baku utama yang dibutuhkan oleh berbagai industri turunan kelapa sawit, seperti minyak goreng, oleo kimia, margarin, sabun serta biodiesel. Setiap tahun kebutuhan akan bahan baku dasar tersebut terus mengalami peningkatan.

Berdasarkan data Statistik Industri Perkebunan Kelapa Sawit Indonesia, hingga tahun 2013, total produksi CPO nasional adalah sebesar 8.975.896 ton. Nilai ini jauh lebih rendah jika dibandingkan dengan total kebutuhan bahan baku untuk seluruh industri yang berkait, yakni sebesar 10.500.525 ton (GAPKI, 2014). 


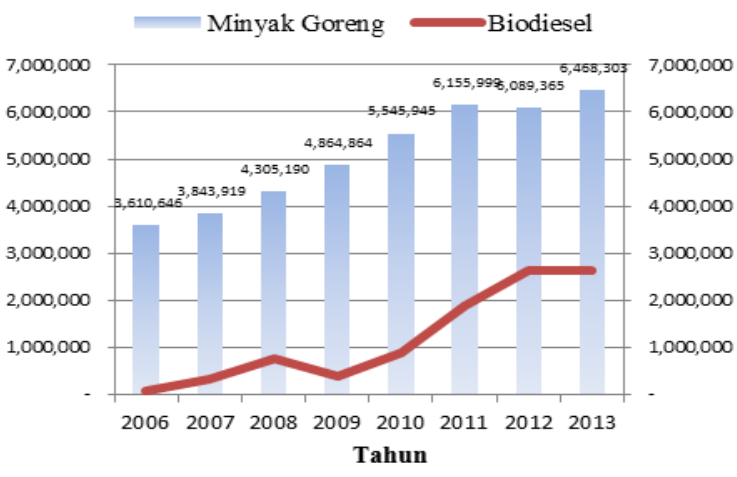

Gambar 3. Grafik Kebutuhan CPO Berbagai Agroindustri Berbasis Kelapa Sawit (GAPKI, 2014)

Kebutuhan bahan baku tertinggi masih didominasi oleh industri minyak goreng, yakni sebesar 6.468 .303 ton $(61,6 \%)$. Sedangkan kebutuhan bahan baku biodiesel hanya sebesar 2.640 .000 ton $(25,2 \%)$. Perbedaan kebutuhan ini pada dasarya disebabkan oleh kapasitas industri yang memang jauh berbeda, dimana kapasitas industri minyak goreng nasional hingga tahun 2007 telah mencapai angka 15.259.884 ton (GAPKI, 2014). Sementara itu kapasitas terpasang industri biodiesel nasional baru mencapai 4.922.622 MT. (EBTKE, 2014).

\section{Konsumsi Dalam Negeri dan Ekspor Biodiesel Kelapa Sawit Nasional}

Konsumsi bahan bakar nabati biodiesel dalam negeri terus mengalami peningkatan dari tahun ke tahun. Pada tahun 2006, tercatat bahwa konsumsi biodiesel nasional hanya $0,06 \%$ dibandingkan dengan konsumsi BBM. Namun pada tahun 2013, terjadi peningkatan yang cukup tinggi, yakni mencapai 5,57\% (USDA, 2014).

Ekspor - impor kelapa sawit Indonesia dilakukan dalam wujud minyak sawit, minyak sawit lainnya, minyak inti sawit dan minyak inti lainnya. Perkembangan volume ekspor kelapa sawit pada tahun 1980-2013 cenderung terus meningkat dengan pertumbuhan rata-rata sebesar $23,52 \%$ per tahun. Pada tahun 1980 volume ekspor kelapa sawit Indonesia hanya sebesar 502,90 ribu ton dengan nilai ekspor sebesar US\$ 254,74 juta, sedangkan tahun 2013 volume ekspor meningkat menjadi 25,79 juta ton senilai US\$ 17,67 milyar (Pusdatin, 2014).

Industri biodiesel nasional hingga tahun 2014 telah berjumlah 26 perusahaan. Skala produksi industri biodiesel berkisar antara 8.000 hinga 1.200.000 KL/ tahun. Salah satu industri biodiesel berbasis kelapa sawit yang telah berkembang dalam bentuk pola klaster adalah yang terdapat di Kawasan Industri Pelintung Dumai.

Berdasarkan data Dirjen Energi Baru Terbarukan dan Konservasi Energi (EBTKE) tahun 2013, rata-rata ekspor biodiesel Indonesia per bulannya adalah sebesar 139.910 KL. Jumlah ekspor biodiesel nasional cukup befluktuasi, dan bahkan mengalami penurunan drastis di akhir tahun 2013 dengan jumlah ekspor pada bulan Desember hanya sebesar $61.814 \mathrm{KL}$. Sementara harga justru mengalami kenaikan dari Rp. 7.000 di bulan Januar naik menjadi Rp. 9000/Lt di Bulan Desember 2013. (Sumber : kip.esdm.go.id/pusdatin. Dirujuk pada tanggal 4 Juni 2015).

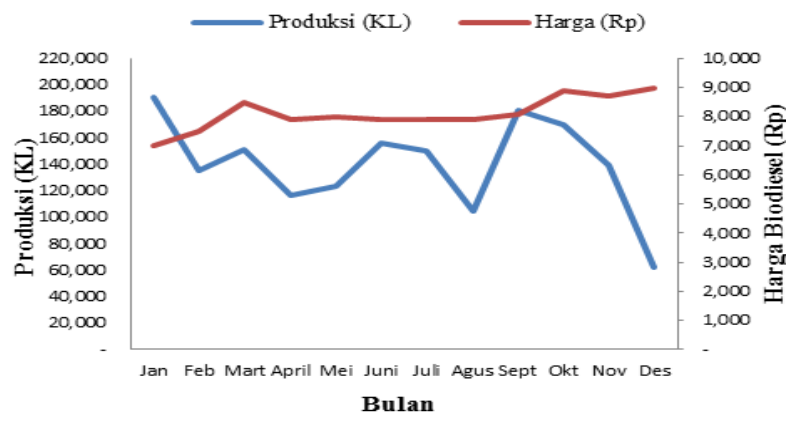

Gambar 4. Grafik Ekspor dan Harga Biodiesel Nasional Per Bulan di Tahun 2013 (EBTKE, 2014)

\section{Perkembangan Klaster Agroindustri Berbasis Kelapa Sawit Nasional}

Berdasarkan potensi yang ada, semenjak tahun 2010 pemerintah melalui Instruksi Presiden Republik Indonesia Nomor 1 Tahun 2010 tentang Percepatan Pelaksanaan Prioritas Pembangunan Nasional Tahun 2010, telah menetapkan Kawasan Industri Pelintung Dumai sebagai salah satu pusat klaster industri berbasis Pertanian dan Oleokimia di Provinsi Riau. Hal ini ditujukan untuk memperkuat pengembangan agroindustri kelapa sawit di tingkat hilir melalui pengolahan bahan baku berbasis kelapa sawit menjadi berbagai produk turunan dalam bentuk industri oleokimia termasuk produk bioenergi (Bappeda Provinsi Riau 2010).

Melalui pengembangan klaster industri ini diharapkan pula dapat memberikan kontribusi bagi upaya pemenuhan kebutuhan bahan bakar nabati. Selain di Provinsi Riau, juga terdapat klaster agrindustri kelapa sawit lainnya, diantaranya di Provinsi Sumatera Utara dan Provinsi Kalimantan Timur.

Tim Tenaga Ahli Klaster Industri Agro yang bernaung dibawah Kementrian Perindustrian Indonesia, telah melakukan evaluasi terhadap perkembangan 11 klaster industri yang ada di Indonesia selama tahun 2012, tiga diantaranya adalah agroindustri berbasis kelapa sawit. Dalam melakukan analisis, tim ini menggunakan empat elemen kunci yang terdiri dari : 1) aglomerasi perusahaan, 2) nilai tambah dan mata rantai nilai, 3) jejaring kerja sama dan 4) infrastruktur ekonomi. Selain itu, dalam menilai perkembangan klaster industri mengacu kepada sembilan kriteria yang dikembangkan oleh Feser (1999) antara lain : 1) innovation, 2) entrepreneurship, 3) workforce skills and availability, 4) network, 5) external connection, 6) social capital, 7) geographic concern, 8) specialized services, dan 9) $R \& D$ capacity. 
Evaluasi penilaian elemen aglomerasi perusahaan dilakukan berdasarkan kepada 9 indikator, yakni : 1) jenis champion, 2) jumlah usaha industri pengolahan, 3) jumlah pemasok bahan baku utama, 4) jumlah pasokan bahan baku pendukung, 5) keberadaan pokja dalam pengembangan klaster, 6) keberadaan lembaga pembiayaan, 7) keberadaan institusi pendidikan, pelatihan dan penelitian, 8) keberadaan industri jasa terkait dan 9) keberadaan asosiasi.

Evaluasi penilaian pada elemen nilai tambah dan rantai nilai, dilakukan berdasarkan kepada 4 indikator yang terdiri dari : 1) capaian hilirisasi, 2) pemanfaatan teknologi, 3) ketersediaan peralatan, 4) kualitas produk. Dari keempat indikator ini diuraikan lagi sehingga menjadi 11 indikator turunan.

Sementara itu, penilaian elemen jejaring kerjasama, dilakukan berdasarkan 12 indikator pengukuran, antara lain : 1) kerjasama cahmpion, 2) kerjasama wirausaha, 3) kerjasama pemasok bahan baku utama, 4) kerjasama pemasok bahan pendukung, 5) kerjasama lembaga pembiayaan, 6) kerjasama institusi pendidikan, pelatihan dan penelitian, 7) kerjasama industri jasa terkait, 8) kerjasama asosiasi, 9) kerjasama pemasaran, 10) peran pokja, 11) peran pemerintah dan 12) peran swasta. Dari 11 indikator utama ini diuraikan lagi menjadi 21 indikator turunan.

Sedangkan pada elemen infrastruktur, penilaian dilakukan berdasarkan kepada lima indikator utama, yaitu :1) Aksesibilitas jalan, 2) Aksesibilitas transportasi (Pelabuhan/ Bandar Udara/Transportasi Darat), 3) Aksesibilitas listrik, Air dan Komunikasi, 4) Aksesibilitas Lahan dan 5) Aksesibilitas Penelitian dan Pengembangan (Litbang). Adapun hasil evaluasi penilaian dari masing-masing elemen memberikan araha prioritas pengembangan seperti terangkum dalam tabel sebagai berikut :

Tabel 1. Prioritas Pengembangan Klaster Menurut Elemen

\begin{tabular}{lll}
\hline \multicolumn{2}{l}{ A. } & Element Aglomerasi Perusahaan \\
\hline No & Lokasi & Prioritas Pengembangan \\
\hline 1 & Riau & - Keberadaan institusi pendidikan, \\
& & pelatihan dan penelitian \\
& & - Keberadaan pokja dalam \\
& & pengembangan klaster \\
& & - Keberadaan industri jasa terkait \\
\hline 2 & Sumut & - Jenis champion skala besar dan \\
& & produk antara \\
& & - Jumlah pemasok bahan baku \\
& & utama \\
\hline 3 & Kaltim & - Menarik perusahaan hilir kelapa \\
& & sawit menjadi champion \\
& & - Jumlah pemasok bahan baku \\
& & utama \\
\hline B. Elemen Nilai & Tambah \\
\hline No & Lokasi & Prioritas Pengembangan \\
\hline 1 & Riau & - Kualitas produk hulu, \\
& & - kualitas produk antara dan \\
& & - capaian hilirisasi \\
\hline
\end{tabular}

\begin{tabular}{|c|c|c|}
\hline 2 & Sumut & $\begin{array}{l}\text { - Kualitas produk hulu, } \\
\text { - kualitas produk antara, } \\
\text { - kualitas produk hilir, } \\
\text { - capaian hilirisasi }\end{array}$ \\
\hline 3 & Kaltim & $\begin{array}{l}\text { - Capaian hilirisasi dan } \\
\text { - kualitas produk hilir }\end{array}$ \\
\hline \multicolumn{3}{|c|}{ C. Elemen Jejaring Kerjasama } \\
\hline No & Lokasi & Prioritas Pengembangan \\
\hline 1 & Riau & $\begin{array}{l}\text { - Kualitas kerjasama industri } \\
\text { pengolahan } \\
\text { - Peran swasta dalam } \\
\text { pengembangan klaster } \\
\text { - Kualitas kerjasama champion } \\
\text { - Kuantitas kerjasama champion }\end{array}$ \\
\hline 2 & Sumut & $\begin{array}{l}\text { - Kualitas kerjasama industri } \\
\text { pengolahan } \\
\text { - Kuantitas kerjasama industri } \\
\text { pengolahan } \\
\text { - Kualitas kerjasama champion } \\
\text { - Kuantitas kerjasama champion }\end{array}$ \\
\hline 3 & Kaltim & $\begin{array}{l}\text { - Kuantitas kerjasama champion } \\
\text { - Kuantitas kerjasama industri } \\
\text { pengolahan } \\
\text { - Peran swasta dalam } \\
\text { pengembangan klaster }\end{array}$ \\
\hline \multicolumn{3}{|c|}{ D. Elemen Infrastruktur Ekonomi } \\
\hline No & Lokasi & Prioritas Pengembangan \\
\hline 1 & Riau & - Aksesibilitas jalan \\
\hline & Sumut & $\begin{array}{l}\text { - Aksesibilitas lahan } \\
\text { - Aksesibilitas transportasi }\end{array}$ \\
\hline & Kaltim & $\begin{array}{l}\text { - Aksesibilitas jalan } \\
\text { - Aksesibilitas transportasi } \\
\text { - Aksesibilitas litbang }\end{array}$ \\
\hline
\end{tabular}

Sumber : Tim Evaluasi Perkembangan Klater Industri (2012)

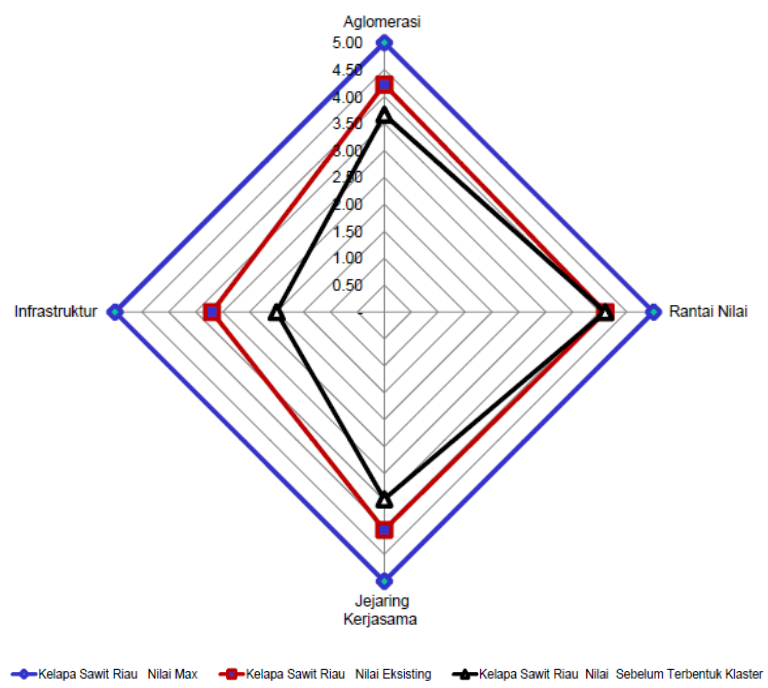

Gambar 5. Pertumbuhan nilai pada klaster kelapa sawit di Provinsi Riau 


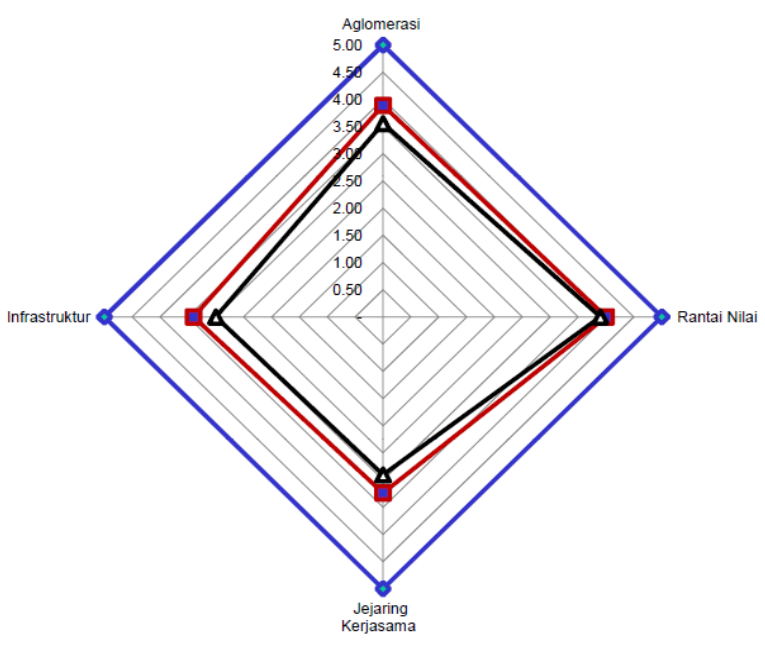

Gambar 6. Pertumbuhan nilai pada klaster kelapa sawit di Provinsi Sumut

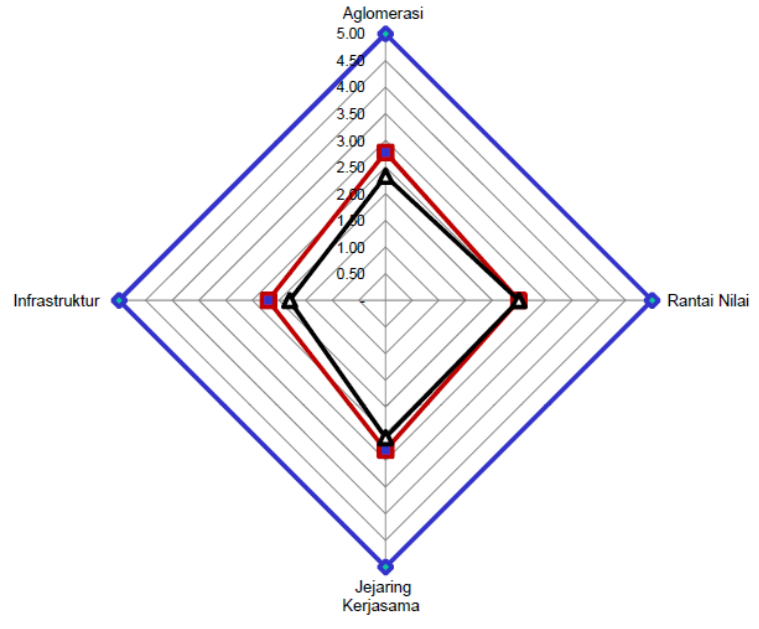

Gambar 7. Pertumbuhan nilai pada klaster kelapa sawit di Provinsi Kaltim

Hasil pengukuran nilai perkembangan klaster kelapa sawit nasional di tiga wilayah provinsi pada tahun 2012 menurut empat elemen yang diperhatikan, terangkum pada tabel sebagai berikut :

Tabel 2. Nilai Perkembangan Setiap Klaster Kelapa Sawit Menurut Empat Elemen

\begin{tabular}{lccc}
\hline \multicolumn{1}{c}{ Elemen } & \multicolumn{3}{c}{ Nilai Eksisting Tahun 2012 } \\
& per Provinsi \\
\cline { 2 - 4 } & Riau & Sumut & Kaltim \\
\hline Aglomerasi & 4,22 & 3,89 & 2,78 \\
Perusahaan & 4,10 & 4,00 & 2,50 \\
Nilai Tambah & 4,05 & 3,24 & 2,81 \\
Jejaring Kerjasama & 3,20 & 3,40 & 2,20 \\
Infrastruktur & & & \\
\hline Sumber : Tim Evaluasi Perkembangan & Klater Industri \\
(2012) & \multicolumn{3}{l}{}
\end{tabular}

Perbandingan nilai total antara ketiga klaster agroindustri kelapa sawit yang ada, pada tahun 2012 dapat dilihat melalui tabel sebagai berikut :

Tabel 3. Perbandingan Perkembangan Klaster

\begin{tabular}{clccc}
\hline $\begin{array}{c}\mathrm{N} \\
\mathrm{o}\end{array}$ & Lokasi & $\begin{array}{c}\text { Nilai } \\
\text { Eksistin } \\
\mathrm{g}\end{array}$ & $\begin{array}{c}\text { Nilai } \\
\text { Sebelum } \\
\text { Terbentukn } \\
(2012)\end{array}$ & $\begin{array}{c}\text { Peningkat } \\
\text { an Nilai }\end{array}$ \\
\hline 1 & Riau & 4,040 & 3,537 & 0,503 \\
2 & Sumut & 3,531 & 3,237 & 0,294 \\
3 & Kaltim & 2,678 & 2,446 & 0,232 \\
\hline
\end{tabular}

Sumber : Tim Tenaga Ahli Klaster Industri Agro (2012)

Berdasarkan hasil evaluasi di atas terlihat bahwa ketiga klaster agroindustri kelapa sawit nasional mengalami peningkatan nilai setelah terbentuknya klaster industri. Klaster industri kelapa sawit di Provinsi Riau, mengalami peningkatan tertinggi dimana sebelum terbentuknya klaster nilai perkembangan yang dapat dicapai adalah sebesar 3,537 dan meningkat menjadi 4,040 .

\section{Kelembagaan pada Klaster Industri Biodiesel Berbasis Kelapa Sawit.}

Keberhasilan pengembangan klaster industri sangat bergantung kepada hubungan kerjasama antar kelembagaan. Hambali E (2005), menyatakan bahwa untuk dapat melaksanakan program pengembangan klaster turunan kelapa sawit, perlu diterapkan 8 kelompok aktivitas. Untuk diperlukan sinkronisasi kerjasama antar kelembagaan seperti terangkum dalam tabel sebagai berikut :

Tabel 4. Kelompok Kelembagaan Klaster Industri Biodiesel Berbasis Kelapa Sawit

\begin{tabular}{|c|c|c|}
\hline No & $\begin{array}{c}\text { Kelompok } \\
\text { Kelembagaan }\end{array}$ & Pelaku Terkait \\
\hline 1 & Pemerintah & \begin{tabular}{lr} 
Departemen & Perindustrian, \\
Departemen & Perdagangan, \\
Departemen & Pertanian, \\
Departemen & Keuangan, \\
Depatemen Energi Sumber Daya \\
\multicolumn{2}{l}{ Mineral, TNI / POLRI }
\end{tabular} \\
\hline 2 & $\begin{array}{l}\text { Praktisi } \\
\text { Industri Inti }\end{array}$ & $\begin{array}{l}\text { Perusahaan Perkebunan } \\
\text { Penyedia Bahan Baku, Industri } \\
\text { Pengolahan CPO dan turunan }\end{array}$ \\
\hline 3 & $\begin{array}{l}\text { Instansi Jasa } \\
\text { Terkait }\end{array}$ & Lembaga Perbankan \\
\hline 4 & $\begin{array}{l}\text { Lembaga } \\
\text { Pendukung }\end{array}$ & $\begin{array}{l}\text { Badan Kerjasama Penanaman } \\
\text { Modal, Lembaga Asosiasi dan } \\
\text { Pendidikan, Lembaga Riset dan } \\
\text { Pengembangan (LIPI/BPPT) }\end{array}$ \\
\hline
\end{tabular}

Sumber : Diadopsi dari Hambali E (2005) 


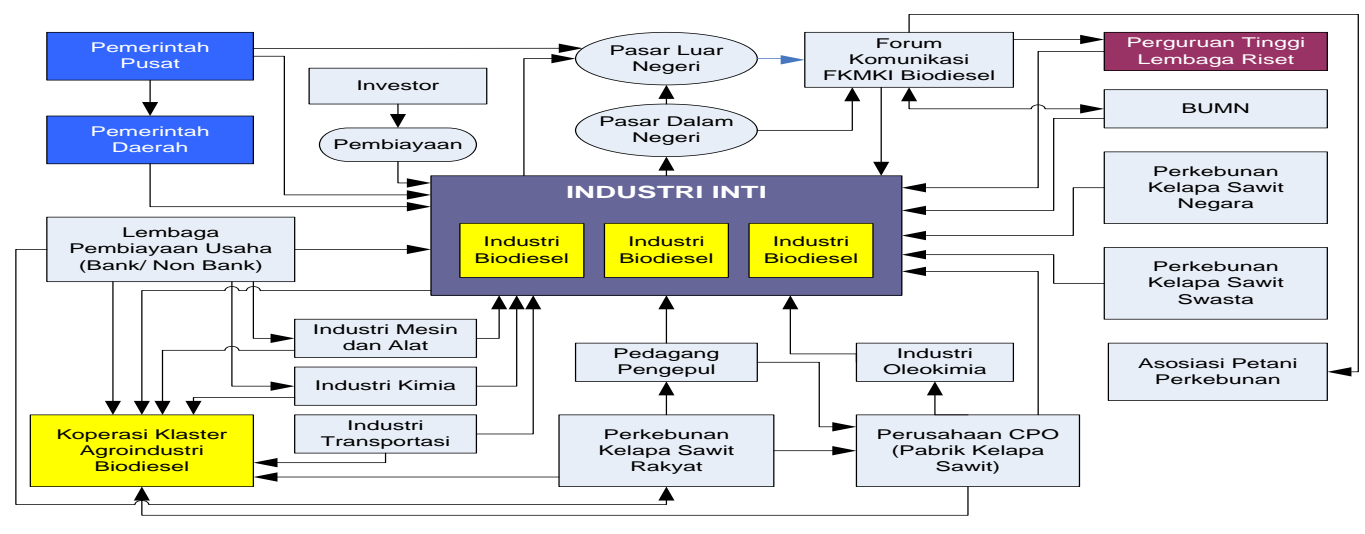

Gambar 8. Klaster Industri Biodiesel Kelapa Sawit (Udayana, 2010)

\section{Implikasi Kebijakan Pemerintah}

Tujuan utama kebijakan industri nasional pada hakekatnya adalah meningatkan volume produksi dengan sekaligus meningkatkan daya saing produkproduk dalam negeri (Tambunan, 2013). Oleh karenanya, penetapan kebijakan mesti memperhatikan berbagai aspek keseimbangan diantara berbagai kepentingan kelompok kelembagaan, terutama kepentingan para pelaku usaha, mulai ditingkat hulu hingga hilir.

Peningkatan daya saing industri biodiesel nasional membutuhkan perhatian lebih dari pemerintah, seperti memberikan subsidi bunga bagi petani kelapa sawit, harmonisasi tarif CPO dengan tujuan menjaga kestabilan harga CPO di tingkat industri, memberikan subsidi pajak kurang lebih 5\% dari kebutuhan biodiesel dan mendorong penggunaan biodiesel pada kendaraan milik pemerintah (Udayana, 2010)

Penetapan harga TBS ditingkat hulu menjadi sangat penting dikarenakan harga beli pabrik terhadap TBS petani saat ini masih yang menganut prinsip "titipolah-jual" cenderung menimbulkan ketidakseimbangan pembagian keuntungan. Said Didu (2000), melalui kajiannya menyatakan bahwa, formulasi perhitungan harga TBS yang ditetapkan pemerintah melalui Kepmen No. 627/Kpts-11/1998 cenderung menimbulkan ketidakadilan pembagian keuntungan. Petani cenderung lebih dirugikan dikarenakan berbagai resiko di tingkat petani sulit diukur secara finansial dan tidak menjadi suatu parameter dalam penetapan formulasi harga TBS.

Begitu pula dengan kebijakan dibidang moneter, banyak memberikan berbagai implikasi bagi kelompok usaha pengolahan, baik pada level industri pengolahan $\mathrm{CPO}$, maupun industri pengolahan produk turunan seperti halnya industri biodiesel kelapa sawit. Pengembangan biodiesel dari minyak kelapa sawit yang dikombinasikan dengan kebijakan kenaikan pajak ekspor sebesar $10 \%$ memberikan dampak yang signifikan pada industri minyak kelapa sawit, dimana akan terjadi peningkatan produksi minyak kelapa sawit sebesar $0,68 \%$, peningkatan konsumsi minyak kelapa sawit domestik sebesar $6,73 \%$, peningkatan harga domestik minyak kelapa sawit sebesar 5,08\% serta peningkatan harga ekspor minyak kelapa sawit sebesar Jurnal Teknik Industri, Vol. XI, No. 2, Mei 2016
$10,62 \%$. Sementara itu, ekspor minyak kelapa sawit mengalami penurunan sebesar 3,70\% (Joni R, 2011).

Lebih lanjut Joni R, (2011), menyatakan bahwa pengembangan biodiesel dari kelapa sawit yang dikombinasikan dengan penurunan suku bunga perbankan sebesar 10\% (suku bunga lebih rendah 10\%) juga memberikan dampak pada industri minyak kelapa sawit. Beberapa pengaruh diantaranya terjadi peningkatan produksi minyak kelapa sawit sebesar $1,53 \%$, peningkatan konsumsi minyak kelapa sawit domestik sebesar $5,92 \%$, peningkatan harga domestik minyak kelapa sawit sebesar $3,71 \%$ serta peningkatan harga ekspor minyak kelapa sawit sebesar $7,85 \%$. Sebaliknya, ekspor minyak kelapa sawit mengalami penurunan sebesar $2,09 \%$.

Selain itu pula, antisipasi terhadap pangaruh krisis finansial yang terjadi saat ini perlu segera diantisipasi melalui kebijakan-kebijakan yang fundamental. Permasalahan krisis finansial yang terjadi secara global, kerap membawa pengaruh terhadap perkembangan industri dalam negeri. Berbagai pengaruh negatif bagi agroindustri kelapa sawit nasional diantaranya dalam bentuk tekanan terhadap harga, penurunan volume ekspor serta penurunan kemampuan produksi (Dradjat, 2011).

Oleh karenanya, dalam menghadapi berbagai tantangan yang ada, diperlukan suatu harmonisasi kebijakan diantara berbagai pemangku kepentingan. Tambunan (2013) menyatakan, bahwa permasalahan di tingkat kebijakan tidak bisa dilimpahkan pada satu lembaga berwenang. Efektivitas dari sebuah kebijakan industri sangat ditentukan oleh adanya harmonisasi diantara berbagai kebijakan yang saling terkait.

Dalam upaya peningkatan daya saing industri nasional, Tambunan (2013) mengelompokkan beberapa level kebijakan yang harus ditetapkan oleh pemerintah, antara lain : 1) kebijakan yang mendukung percepatan pengembangan kawasan industri, 2) kebijakan dibidang peningkatan kemampuan teknologi dan inovasi, 3) kebijakan hilirisasi industri, 4) kebijakan peningkatan standarisasi produk, 5) kebijakan moderniasi pabrik, serta 6) kebijakan yang mendorong ekspor produk unggulan. 


\section{Kesimpulan}

Program klaster industri telah memberikan pengaruh yang positif bagi pengembangan agroindustri kelapa sawit nasional beserta berbagai industri produk turunanya, seperti halnya biodiesel. Namun, untuk dapat lebih meningkatkan daya saing, diperlukan pula berbagai langkah nyata dengan melibatkan berbagai peran kelembagaan yang berkepentingan.

Penetapan kebijakan menjadi faktor kunci bagi upaya peningkatan daya saing agroindustri nasional. Harmonisasi dan keterpaduan kebijakan merupakan titik awal demi teriptanya efektivitas penerapan dalam rangka pencapaian target-target pemenuhan kebutuhan berbagai tingkat kepentingan, khususnya kepentingan berbagai pihak dan kelembagaan. Evaluasi dan perbaikan berkelanjutan terhadap berbagai aspek, menjadi tonggak utama dalam upaya peningkatan daya saing agroindustri nasional secara berkelanjutan. Penguatan daya saing industri biodiesel kelapa sawit nasional harus terus diupayakan agar industri biodiesel nasional mampu berbicara dan diakui dalam persaingan bisnis global.

Daftar Pustaka

Bappeda Provinsi Riau, 2010., Laporan Akhir Feasibility Study Klaster Industri Berbasis Pertanian dan Olekimia di Kota Dumai

Biomass Energy Europe. 2010a. "Harmonization of Biomass Resource Assessments, Volume I: Best Practices and Methods Handbook". BEE: Freiburg-Germany

BPPT. 2011. Mapping Potensi dan Penyediaan Bahan Baku Bioenergi Nasional. Indo Bioenergy 2011. Jakarta.

Ceglie G, Dini M, 1999). SME Cluster and Network Development in Developing Countries : The Experience of UNIDO. Vol 2 PSD Technical Working Papers Series.

Deptan. 2014. Statistik Perkebunan Indonesia

Dradjat B, 2011. Dampak Krisis Finansial Global dan Kebijakan Antisipasi Pengembangan Industri Kelapa Sawit. Jurnal Analisis Kebijakan Pertanian. Vol 9 (3) : 237-260.

EBTKE, 2014. Statistik Energi Baru Terbarukan dan Konservasi Energi Tahun 2014.

Feser dan Bergman, 1999, "National Industry Cluster Tempaltes : A Framework for applied Regional Clustery Analysis" Regional Studiese Journal 34 $: 1,2000$.

GAPKI, 2014. Industri Minyak Sawit Indonesia Menuju 100 Tahun NKRI. Membaungan Kemandirian Ekonomi, Energi dan Pangan secara Berkelanjutan.

Hambali E, 2010. The Potential of Oil Palm and Rice Biomass as Bioenergy Feedstock. $7^{\text {th }}$ Asia Biomass Workshop Jakarta. Indonesia.

Hambali E, 2005. Pengembangan Klaster Industri Turunan Minyak Kelapa Sawit. Proceeding Seminar Nasional Pemanfaatan Oleokimia Berbasis Minyak Sawit pada Berbagai Industri.
Hidayat S, 2012. Kesetaraan Nilai Tambah pada Rantai Pasok Agroindustri Kelapa Sawit yang Terintegrasi. Proceeding Seminar Nasional dan Kongres MAKSI. Bogor. Indonesia.

Joni R. 2011. Dampak Pengembangan Industri Biodiesel dari Kelapa Sawit terhadap Perkebunan Kelapa Sawit dan Industri Minyak Kelapa Sawit di Indonesia. Jurnal Teknologi Industri Pertanian Vol. 20 (3) : 143-151.

Menzel dan Fornahl, 2009. Cluster Life Cycles Dimensions and Rationales of Cluster Evolution. Jurnal Industrial and Corporate Change Vol. 19 (1) : 205-238.

Porter ME. 2000. Local, Competition and Economic Development : Local Cluster in a Global Economy. Jurnal Economic Development Quarterly, Vol 14 (1) : 15-34. Harvard Business Review.

Pusdatin, 2014. Statistik Pertanian Indonesia Tahun 2014. Jakarta.

Roelandt dan den Hertog, 1999. Cluster Analysis and Cluster Policy in Netherlands. OECD Proceeding Boosting Innovation : The Cluster Approach.

Said Didu, 2000. Rancang Bangun Strategi Pengembangan Agroindustri Kelapa Sawit. Jurnal Teknologi Industri Pertanian Vol. 11(1):20-26.

Sari DM. 2008. Analisis Daya Saing dan Strategi Ekspor Kelapa Sawit (CPO) Indonesia di Pasar Internasional. [Skripsi]. Bogor : Fakultas Ekonomi dan Manajemen, Institut Pertanian Bogor.

Soerawidjaja TH, 2011. Rintangan-rintangan Percepatan Implementasi Bioenergi. Makalah Seminar KADIN "Memasuki Era Energi Baru dan Terbarukan untuk Kedaulatan Energi Nasional" Jakarta.

Tambunan Dkk, 2013. Kebijakan Industri dalam Menyosngsong ME-ASEAN 2015. Policy Paper Edisi 16 April 2013.

Tan J, 2006. Growth of industry clusters and innovation : Lessons from Beijing Zhongguancun Science Park. Journal of Business Venturing 21 : $827-$ 850.

Tim Tenaga Ahli Klaster Industri Agro, 2013. Perkembangan dan Evaluasi Klaster Industri Agro, 2012.

Udayana, 2010. Manajemen Resiko Agroindustri Biodiesel Berbasis Kelapa Sawit. [Disertasi] Pascarsarjana Institut Pertanian Bogor.

USDA, 2014. Indonesia Biofuel Annual 2014. Jakarta

Utama DN, 2012. Sistem Penunjang Keputusan Cerdas untuk Pencarian Jalur Optimum Rantai Pasok Bioenergi Berbasis Kelapa Sawit dengan Menggunakan Metode Optimasi Koloni Semut. Jurnal Teknologi Industri Pertanian Vol 21(1):50-62. 